\title{
Public Libraries and Student's Information Needs in Democratic Society
}

\author{
Robert Janus, Darko Lacovic \\ Department of Information Sciences, University of Josip Juraj Strossmayer, Osijek, Croatia
}

Email address:

rjanus@ffos.hr (R. Janus), dlacovic@ffos.hr (D. Lacovic)

\section{To cite this article:}

Robert Janus, Darko Lacovic. Public Libraries and Student's Information Needs in Democratic Society. International Journal of Intelligent Information Systems. Vol. 6, No. 2, 2017, pp. 21-24. doi: 10.11648/j.ijiis.20170602.12

Received: May 5, 2017; Accepted: May 20, 2017; Published: May 27, 2017

\begin{abstract}
The goal of this research was to examine information needs of students in democratic society with the emphasis on their perception and use of the public library in satisfying democratic and civil rights. In the research were used quantitative methodology (printed questionnaires) and participants were students of information sciences in Osijek (Croatia). Although research results showed that students mostly never $(41 \%)$ or rarely $(40 \%)$ searched for the information regarding their civil and democratic rights, they found that these rights were mostly important to them (mean 3.28). Less than a half of the respondents had information needs for democratic and civil rights in the area of education (42\%). As expected more than a half of the respondents informed themselves about civil and democratic rights over the Internet (57\%), while only $6 \%$ of them looked for that information in public libraries. Students mainly agreed that public libraries should provide access to the civil and democratic rights information (mean 4.13) by preparing public lectures, discussions, workshops or appropriate materials such as brochures (63\%). Research data can be useful for public libraries in organizing collections and services for the support of democracy and civil rights.
\end{abstract}

Keywords: Information Needs, Students, Public Libraries, Democracy, Civil Rights

\section{Introduction}

Democratic and civil rights are the part of main human rights which are first of all described in the Universal Declaration of Human Rights [1]. According to International Covenant on Civil and Political Rights everyone can enjoy freedom of his civil, political, economic, social and cultural rights, while every democratic society needs to be supported by the respect for human rights, freedom of expression or opinion, periodic elections, transparency of public administration, independent and pluralistic media etc. [2, 10]. Lor and Britz [3] consider that freedom of information requires development of ICT infrastructure and that knowledge society is not possible without free access to information. Democracy development is only possible through the free and unlimited access to thought, information, knowledge, culture, education and active participation in the society $[4,10]$.

From the very beginning of their existence, libraries kept safe some of the most important ideals of society today, one of which is democracy. Kranich [5] states that the public libraries are the cornerstone of democracy in communities because they assist the users in locating a diversity of resources and in developing the information literacy skills necessary to become responsible, informed citizens and to participate in democracy. She continues claiming that libraries participate in every aspect of information society and disseminate information so the public can engage in selfgovernance. Libraries should provide democracy development and ensure access to all kinds of community information regarding knowledge and culture [4]. However, some citizens are often not aware of the benefits if they use their right to inform themselves within the libraries free of charge. Furthermore, not only users don't use their right to inform themselves properly, but sometimes, according to Lor and Britz [3], governments in various parts of the world see free access to information as a threat, and take measures to control or limit access to the internet (or other channels of informing). The question they raise is whether a knowledge society can evolve in the absence of information freedom and 
how do student population perceive this issue.

Public libraries have an important role in a democratic society. Kranich [5] indicates that public libraries are democratic institutions in several reasons: they offer access to government information, provide information resources in all its forms, disseminate information for the people from the information society and ensure spaces for the public dialogue in order to gain a freedom of speech. As politically neutral institutions public libraries should offer physical and virtual spaces in which community members can exchange ideas related to democracy and civil rights. Kranich [5] also emphasizes that librarians educate the users to identify and evaluate information for decision making in the different areas of life such as learning and working. Katic [6] reveals that public libraries should offer information regarding elections, government, local community and to possess books and journals about politics and democracy. As well as Kranich [5] he also claims that library spaces could serve for democratic discussion through organization of lectures, debates, workshops etc. It is important that public libraries encourage citizens to participate in the development of civil society [6, 12]. New public library buildings should be democratic, sustainable and sustaining in order to enable active participation of citizens in their physical and virtual spaces [7]. One example of new building is Aarhus public library which includes spaces for social learning and democracy activities [8].

De la Pena McCook and Phenix [9] indicate that citizens can make the successful decisions since the public libraries provide access to information and value knowledge, justice, truth, culture and books offering various lifelong services. For example, one research study showed that public libraries in Nigeria are inadequate to suport democracy with their resources and services [9].

In this paper authors present and discus results of the small study concerning information needs of students for the democracy and civil rights as well as their attitudes about importance and use of public libraries in a Croatian democratic society.

\section{Methodology}

The aim of the study was to examine information needs of students in a democratic society and to reveal their perception and use of the public library regarding democratic and civil rights. The study was based on three research questions:

a) What are information needs of students in relation to their democratic and civil rights?

b) What kind of information sources do students use to inform themselves about democracy and civil rights (newspapers, internet, radio, TV)?

c) How do students perceive and use public libraries for purpose of democracy?

The research was conducted with the help of quantitative methodology. Printed questionnaires were distributed during September 2015 to the students of information sciences at the
Faculty of Humanities and Social Sciences (University of Osijek) in Croatia. In a survey participated 100 students are at the undergraduate and graduate level. The questionnaire consisted of 12 questions divided into three groups: background information about the respondents, questions about student's comprehension and use of the civil and democratic rights and questions related to the parliament elections in Croatia which gave a broader picture of how students engaged themselves in a civil and democratic society. The questionnaire had five closed multiple-choice questions with no possibility of providing additional answers; three multiple-choice questions with the possibility of providing additional answers if none of the given options were satisfactory to the respondents; one of Thurstone and Likert scaling question; and two opened questions.

\section{Research Results}

The questionnaire was completed by 100 respondents of which more females (78\%) than males responded (22\%). Regarding education level, predominant were undergraduate respondents $(79 \%)$, while there was less students on graduate level $(21 \%)$.

According to the results a vast majority of information science students never $(41 \%)$ or rarely $(40 \%)$ searched for the information related to the civil and democratic rights in a past year-time period. Less number of students searched for the information occasionally (17\%), while only some students searched for the information often $(2 \%)$ and no one very often.

As expected most covered area in student's information needs regarding civil and democratic rights was education (42\%). Employment (21\%), official information (19\%) and expression of political views $(17 \%)$ were next most frequent topics. Somewhat lesser number of students replied that they needed information for the freedom of speech and freedom of opinion expression (14\%), healthcare (11\%), and law equality $(11 \%)$. Information about freedom on property $(6 \%)$ and freedom of assembly (5\%) were the least mentioned topics. The results are presented in Table 1.

Table 1. Information needs for democratic and civil rights.

\begin{tabular}{ll}
\hline Information needs & Percentage \\
\hline education & $42 \%$ \\
employment & $21 \%$ \\
official information & $19 \%$ \\
expression of political views & $17 \%$ \\
freedom of speech and opinion expression & $14 \%$ \\
healthcare & $11 \%$ \\
law equality & $11 \%$ \\
freedom on property & $6 \%$ \\
freedom of assembly & $5 \%$ \\
\hline
\end{tabular}

Almost all students who rarely, occasionally or often searched for the information related to the civil and 
democratic rights in a past year $(n=56,93.3 \%)$ stated that they used e-sources, while only few respondents looked for those information in printed sources $(n=4,6.67 \%)$. The results presented in Table 2 showed that more than a half of the respondents used Internet (57\%) for informing themselves about civil and democratic rights, while less than a quarter informed themselves on TV $(20 \%)$, or consulting other people $(15 \%)$ and newspapers $(11 \%)$. Public libraries $(6 \%)$ and radio $(4 \%)$ were the least frequent used sources when searching for the information regarding civil and democratic rights. The respondents indicated that the main reasons for using information sources were easy accessibility $(52 \%)$ and simplicity (40\%) followed by habit $(30 \%)$. The least mentioned reasons were: not knowing where to look for the sources $(5 \%)$, recommendation of colleagues or friends $(3 \%)$ and other sources $(1 \%)$.

Table 2. Information sources about democracy and civil rights.

\begin{tabular}{ll}
\hline Information sources & Percentage \\
\hline Internet & $57 \%$ \\
TV & $20 \%$ \\
other people & $15 \%$ \\
newspapers & $11 \%$ \\
public libraries & $6 \%$ \\
radio & $4 \%$ \\
\hline
\end{tabular}

For the next question respondents had to assess the importance of civil and democratic rights information to them on a scale of 1 to $5(1=$ not important, $5=$ very important), and the results revealed that $18 \%$ of respondents considered civil and democratic rights information not at all $(1=5 \%)$ or not so important $(2=13 \%)$, while the majority of the respondents $(82 \%)$ thought that civil and democratic rights were important $(3=44 \%, 4=23 \%, 5=15 \%)$. In average respondents consider that information on democratic and civil rights are mostly important to them (mean 3.28). In the next question respondents had to assess their agreement with 7 statements related to their participation in a democratic society and the role of the public libraries regarding the civil and democratic rights on the scale of 1 to $5(1=$ strongly disagree, $5=$ strongly agree). As can be seen from the Table 3, respondents mainly agreed with the statement that "Public libraries should provide access to the civil and democratic rights information" (mean 4.13), followed by "Public libraries should organize public lectures and workshops about civil and democratic rights" (mean 3.38), "Public libraries are adequate places for discussion on civil and democratic rights" (mean 3.33), "I'm well informed about my civil and democratic rights" (mean 3.01), "In my local community information about civil and democratic rights are heavy accessible" (mean 2.89), "I consider myself to be a proactive citizen of my community" (mean 2.76) and "Public libraries jeopardize their political neutrality by acquisition of civil and democratic rights information sources" (mean 1.9).
Table 3. Agreement to the statements on democracy and civil rights.

\begin{tabular}{ll}
\hline Statements & Mean \\
\hline $\begin{array}{l}\text { Public libraries should provide access to the civil and democratic } \\
\text { rights information }\end{array}$ & 4.13 \\
$\begin{array}{l}\text { Public libraries should organize public lectures and workshops } \\
\text { about civil and democratic rights }\end{array}$ & 3.38 \\
$\begin{array}{l}\text { Public libraries are adequate places for discussion on civil and } \\
\text { democratic rights }\end{array}$ & 3.33 \\
$\begin{array}{l}\text { I'm well informed about my civil and democratic rights } \\
\text { In my local community information about civil and democratic } \\
\text { rights are heavy accessible }\end{array}$ & 3.01 \\
$\begin{array}{l}\text { I consider myself to be a proactive citizen of my community } \\
\text { Public libraries jeopardize their political neutrality by acquisition } \\
\text { of civil and democratic rights information sources }\end{array}$ & 2.89 \\
\hline
\end{tabular}

Additionally, respondents were asked to propose the ways in which public libraries should contribute to the democratization of population. More than half of those students who answered this question (63\%) indicated that public libraries could affect the democratic development of the society by organizing the lectures, workshops, public classes, presentations (informing and education); by preparing brochures, flyers, literature, projects and programs, by population involvement through discussions, meetings, cooperation, and surveys.

In relation to the participation in Croatian Parliament elections, results showed that more than a half of the students voted $(53 \%)$ and the others elaborated that they didn't voted for further reasons: lack of time to vote $(n=19,42.22 \%)$, uninterested or apolitical and uninformed $(n=11,24.44 \%)$, undecided $(\mathrm{n}=4,8.88 \%)$, and lack of confidence or quality choice $(n=3,6.66 \%)$.

\section{Conclusion}

Public libraries should have an important or even central role when it comes to democratization of the society. Being able to inform themselves should be a basic right of all society's participants, especially where society claims to be civil and democratic. Active participation in all aspects of civil and democratic activities should be citizens' responsibility. Students (and other citizens) can acquire civil and democratic rights information often entirely free of charge in public libraries. However, this research indicated that most of them did not use it, or they did use it in a rare occasions. In that sense it would be necessary to raise the awareness of civil and democratic rights and responsibilities, and to point out benefits citizens might gain from doing so. All of the respondents were students of the same University attending the information science curriculum, so the data collected may reflect important variables that influence and cause their distinctive behaviour when it comes to practicing their civil and democratic rights in the community. These variables might be more of a personal nature and reveal what is that makes students from the same education-background act differently regarding this issue.

The research revealed that students mostly used electronic sources $(93 \%)$, primarily Internet $(57 \%)$. In relation to the information sources most of the respondents answered they 
chose their source regarding simplicity, habit and easy accessibility. Furthermore, respondents mostly had information needs from the education field (42\%), which was expected since they are students. Assuming they were obliged to search for academic information, yet another indication implies that respondents were mostly extrinsically motivated. Although the majority of the respondents never or rarely searched for information regarding civil and democratic rights, they are aware that information about civil and democratic rights are important (mean 3.28). Students who didn't voted on the parliament elections indicated that they were mostly unmotivated or undecided to give their voice.

Even though respondents didn't show high interest in civil and democratic information rights when they had to take initiative, they gave quite positive assessments to the statements related to access to the civil and democratic rights information within the public libraries (4.13), as well as their role in organization of public lectures, workshops and discussions (3.38). Next research should go in the direction of examining what specific topics would students like to be covered, and what is that would attract them to those events, since motivation turned out to be a crucial factor in such cases.

Reasonable conclusion given collected data would be to encourage both public libraries and respondents to be more active regarding democracy and civil rights. Libraries should indeed organize and promote more activities, while students should take more responsibility to their civil and democratic rights.

\section{References}

[1] The Universal Declaration of Human http://www.un.org/en/universal-declaration-humanrights/index.html
[2] The United Nations. International Covenant on Civil and Political Rights, 1994. http://www1.umn.edu/humanrts/undocs/vs41250e.pdf

[3] Lor, P. J., Britz, J. J. "Is a knowledge society possible without freedom of access to information." Journal of Information Science, 2007, vol. 33, no. 4, pp. 387-397.

[4] UNESCO Public Library Manifesto. http://www.unesco.org/webworld/libraries/manifestos/librama n.html

[5] Kranich, N. Libraries, the Internet, and democracy. American Library Association, 2001.

[6] Katic, Miroslav. "Libraries and democracy: the role of libraries in development of a deliberative democracy." Public libraries as third place. Proceedings. Zagreb: National and University Library, 2015.

[7] Blewitt, John. "Public libraries, citizens and the democracy." Power and Education, 2014, vol. 6, no. 1, pp. 84-98. http://journals.sagepub.com/doi/pdf/10.2304/power.2014.6.1.8 4

[8] City of Aarhus. Urban Mediaspace Aarhus, 2013. http://www.urbanmediaspace.dk/sites/default/files/pdf/ums ha efte_2011_uk.pdf

[9] De la Pena McCook, K., Phenix, K. J. "Public libraries and human rights." Public Library Quarterly, 2006, vol. 25, no. 12, pp. 57-73. http://dx.doi.org/10.1300/J118v25n01_05

[10] Nwofor, Amaka Florence, Chinyere, Ilorah Hope Mrs. "Sustaining Nigeria's democracy: Public libraries as an indispensable instrument in Anambra state." Library Philosophy and Practice, 2015. http://digitalcommons.unl.edu/cgi/viewcontent.cgi?article=32 $07 \&$ context=libphilprac

[11] European Commission. Democracy and human rights. https://ec.europa.eu/europeaid/sectors/human-rights-andgovernance/democracy-and-human-rights_en

[12] Pateman, J. \& Vincent, J. Public libraries and social justice. Farnham: Ashgate, 2010. 